\title{
High-Efficiency Dye-Sensitized Solar Cell with Three-Dimensional Photoanode
}

\author{
Nicolas Tétreault, ${ }^{*,+}$ Éric Arsenault, ${ }^{\ddagger}$ Leo-Philipp Heiniger, ${ }^{\dagger}$ Navid Soheilnia, ${ }^{\ddagger}$ Jérémie Brillet, ${ }^{\dagger}$ \\ Thomas Moehl, ${ }^{+}$Shaik Zakeeruddin, ${ }^{+}$Geoffrey A. Ozin, ${ }^{*,+}$ and Michael Grätzel ${ }^{\dagger}$ \\ ${ }^{\dagger}$ Laboratory of Photonic and Interfaces, Institute of Physical Chemistry, École Polytechnique Fédérale de Lausanne, 1015 Lausanne, \\ Switzerland \\ ${ }^{\ddagger}$ Materials Chemistry and Nanochemistry Research Group, Center for Inorganic and Polymeric Nanomaterials, Department of \\ Chemistry, University of Toronto, 80 St. George Street, Toronto, Ontario M5S 3H6, Canada
}

Supporting Information

ABSTRACT: Herein, we present a straightforward bottom-up synthesis of a high electron mobility and highly light scattering macroporous photoanode for dye-sensitized solar cells. The dense three-dimensional Al/ $\mathrm{ZnO}$, $\mathrm{SnO}_{2}$, or $\mathrm{TiO}_{2}$ host integrates a conformal passivation thin film to reduce recombination and a large surfacearea mesoporous anatase guest for high dye loading. This novel photoanode is designed to improve the charge extraction resulting in higher fill factor and photovoltage for DSCs. An increase in photovoltage of up to $110 \mathrm{mV}$ over state-of-the-art DSC is demonstrated.

KEYWORDS: Phovoltaic devices, dye-sensitized solar cells, host-guest, self-assembly, transparent conductive oxides

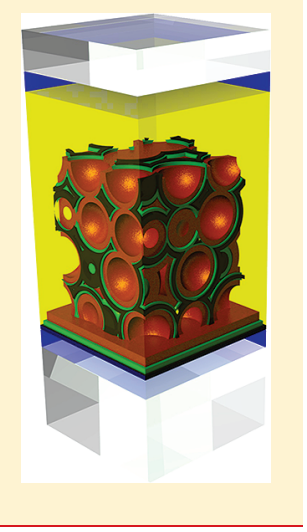

$\mathrm{D}$ ye-sensitized solar cells (DSCs) are one of the most promising photovoltaic technologies for production of renewable, clean, and affordable energy. They are generally made from cheap and nontoxic components and can be designed in a variety of different colors and transparencies, which distinguishes them as an ideal photovoltaic concept for integrated "green" architecture. Additionally, they have been shown to be competitive with other thin film technologies reaching certified efficiencies as high as $11.1 \%$ when using a triiodide/iodide $\left(\mathrm{I}_{3}^{-} / \mathrm{I}^{-}\right)$redox shuttle. ${ }^{1-3}$

In DSCs, charge carrier generation takes place in a chemisorbed monolayer of photoactive dye that is sandwiched between a semiconducting oxide, usually anatase $\mathrm{TiO}_{2}$, and an electrolyte acting as electron and hole conducting materials, respectively. Because of the relatively low-absorption cross-section of the molecular sensitizer, a high surface area mesoscopic photoanode is necessary to ensure high dye loading and efficient light harvesting in the visible part of the solar spectrum. This implies that the DSC has an exceedingly large, heterogeneous interface through which electrons may be (parasitically) intercepted as a result of the slow electron transport. The latter is governed by an ambipolar diffusion mechanism controlled by trap-limited hopping through a relatively long and tortuous path to the transparent conductive electrode. $^{4-9}$ It is further hindered by the low electron mobility in anatase $\mathrm{TiO}_{2}$ nanoparticles and the multiple grain boundaries in the mesoporous film. ${ }^{8}$

Given a charge collection time of milliseconds at the maximum power point, ${ }^{9}$ efficient charge extraction is only made possible when using the $\left(\mathrm{I}_{3}^{-} / \mathrm{I}^{-}\right)$redox couple through the slow interception of electrons by adjacent $\mathrm{I}_{3}{ }^{-10}$ In addition to limited light harvesting by the dye, one of the main limiting factors of efficiency is the excessive driving force of $0.6 \mathrm{eV}$ necessary for the dye-regeneration process leading to a significant loss-in-voltage of approximately 600 $\mathrm{mV}$. $^{7,112}$ This has sparked development and study of various alternative redox couples including p-type semiconductors. ${ }^{13}$ Increasingly, development has been centered around the use of organic hole-transporting materials (HTM) in solid-state DSCs (ss-DSCs). ${ }^{14-17}$

The electronic loss that is typically discussed for DSCs is slow transport-induced recombination. ${ }^{18-21}$ If charges recombine before reaching the electrode then this has a direct influence on the photocurrent and photovoltage. The open-circuit voltage is defined by the splitting of the quasi-Fermi level of electrons in the metal oxide and the redox potential of the electrolyte (quasiFermi level of holes in the hole-transporter). Hence, the closer the Fermi level in the metal oxide can be pushed toward the conduction band and LUMO level of the sensitizer, the higher the open-circuit voltage, and the smaller the loss-in-potential going from the level of the excited state of the dye to the quasiFermi level in the metal oxide. Two strategies can contribute to this upward shift and increase the open-circuit potential, namely reducing the recombination rate constant enabling the Fermi level to move closer to the conduction band before the recombination

\section{Received: May 26, 2011}

Revised: September 25, 2011

Published: September 30, 2011 


\section{(A)}

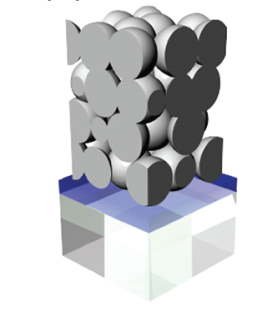

(D)

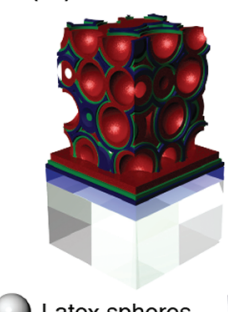

Latex spheres
(B)

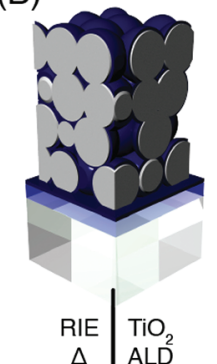

(C)

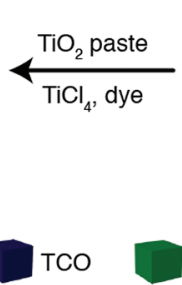

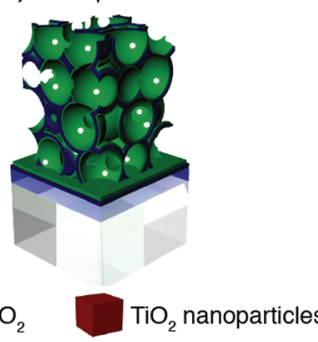

(E)

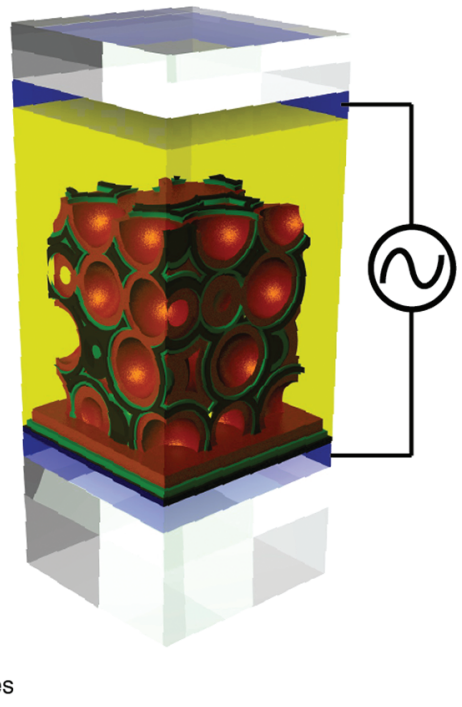

Figure 1. Schematic representation of the synthesis method for a 3D host-guest dye-sensitized solar cell. (A) Doctor-bladed, disordered template of $2.2 \mu \mathrm{m}$ polystyrene spheres. (B) Layer-by-layer conformal deposition of the host material $\left(\mathrm{Al} / \mathrm{ZnO}, \mathrm{TiO}_{2}\right)$ by ALD. (C) After RIE to open the top surface, the template is removed by annealing at $360^{\circ} \mathrm{C}$ to reveal a disordered inverse opal of host material. It is then conformally coated with $25 \mathrm{~nm}$ of dense $\mathrm{TiO}_{2}$ by ALD. (D) Pore filling with high surface area nanocrystalline $\mathrm{TiO}_{2}$ and dye loading. (E) Liquid electrolyte infiltration and sealing of the dye sensitized solar cell.

rate balances the charge generation rate or shifting the conduction band itself. Finally, enhancing the electron transport could improve charge collection and reduce IR losses, enhance the short-circuit current, and fill factor. ${ }^{12,18}$

Several approaches have been proposed in order to reduce interfacial recombination and improve charge collection in liquid electrolytes and ss-DSCs including the use of radial collection nanostructures, ${ }^{7}$ one-dimensional $\mathrm{ZnO}$ and $\mathrm{TiO}_{2}$ nanorods, and nanowires as photoanodes. ${ }^{22-25}$ Even though these approaches show great promise, they have yet to achieve power conversion efficiencies above 5\% in liquid electrolyte DSCs and $1.7 \%$ in ssDSCs. Lately, we were able to show faster electron transport using a novel three-dimensional (3D) self-assembled anatase $\mathrm{TiO}_{2}$ fibrous network photoanode capable of enhanced light harvesting and charge transport to reach an efficiency of 5\%, a record for nanowire-based ss-DSCs. ${ }^{26}$

Particular attention has been given to $\mathrm{ZnO}$ and $\mathrm{SnO}_{2}$ as alternatives to $\mathrm{TiO}_{2}$ in DSCs due to their higher electronic conductivity and electron mobility when compared to $\mathrm{TiO}_{2}{ }^{27}$ Despite faster electron transport, ${ }^{27}$ only rather poor device efficiencies have been reported to date for DSCs employing nanocrystalline $\mathrm{SnO}_{2}{ }^{7,23,28-30}$ In part, this was found to be due to a $2-3$ orders of magnitude increase in the recombination rates when the high mobility material is in direct contact with the sensitizer and/or the electrolyte. ${ }^{27}$ This finding led to a host of publications on the addition of blocking (passivating) layers covering the $\mathrm{ZnO}$ or $\mathrm{SnO}_{2}$ in order to reduce this recombination rate resulting in higher photovoltage. $7,31,32$

Herein, we demonstrate a novel bottom-up 3D host-passivation-guest (H-P-G) electrode concept that enables structural control on the electron extraction, conduction band, and the recombination dynamics as well as on the optical scattering in photovoltaic devices. This new type of electrode is exemplified herein by incorporating it into a DSC photoanode to significantly improve photocurrent, fill factor, and most importantly the photovoltage. This is shown through a strong decrease in dark current when comparing a $3 \mathrm{D} \quad \mathrm{TiO}_{2}$ host to high electron mobility $\mathrm{Al} / \mathrm{ZnO}$ and $\mathrm{SnO}_{2}$ hosts. To ensure high dye loading, the macropores contained in the passivated $3 \mathrm{D}$ host are infiltrated with anatase $\mathrm{TiO}_{2}$ nanoparticles to form a conformal mesoporous film enabling optimized sensitization and electron injection characteristics found in traditional nanoparticle-based DSCs. Using this novel architecture, an increase in the photovoltage of up to $110 \mathrm{mV}$ over state-of-the-art $\mathrm{TiO}_{2}, \mathrm{ZnO}$, and $\mathrm{SnO}_{2}$-based DSCs is obtained. The straightforward and simple bottom-up fabrication technique produces a highly optically scattering photoanode that could enable enhanced light harvesting, ${ }^{1}$ fast charge extraction, reduced interfacial recombination, and lower IR loss to significantly increase the cell photovoltage, photocurrent, and the fill factor. ${ }^{12}$ The concept electrode is well suited for DSCs since only a small volume fraction is lost to the optically inactive $3 \mathrm{D}$ host material leaving most of the volume for the light harvesting sensitized nanoparticle $\mathrm{TiO}_{2}$ mesoporous film.

A schematic representation of the intermediate materials involved in the fabrication of a 3D H-P-G photoanode for DSCs is shown in Figure 1. The overall fabrication method is inspired by micromolding in inverse opals (MISO) first developed for the synthesis of large-area oxide inverse opals and then extended for high-temperature fabrication of full-photonic bandgap semiconductor photonic crystals from polymer templates. ${ }^{33,34}$ In particular, a dispersion of polystyrene macrospheres in isopropanol is used to accelerate the capillary force-induced self-assembly of the polystyrene macrospheres $(\Phi=2.2 \mu \mathrm{m})$ and thereby obtain a highly disordered opal template of uniform thickness. Using large monodispersed spheres enables the formation of a uniform template with predictably large interconnecting pores extending in all three spatial dimensions. The thickness of the template is adjusted through the volume concentration of spheres in the isopropanol dispersion ( 22 vol $\%$ for $10-12 \mu \mathrm{m}$ thick template film). 
(A)

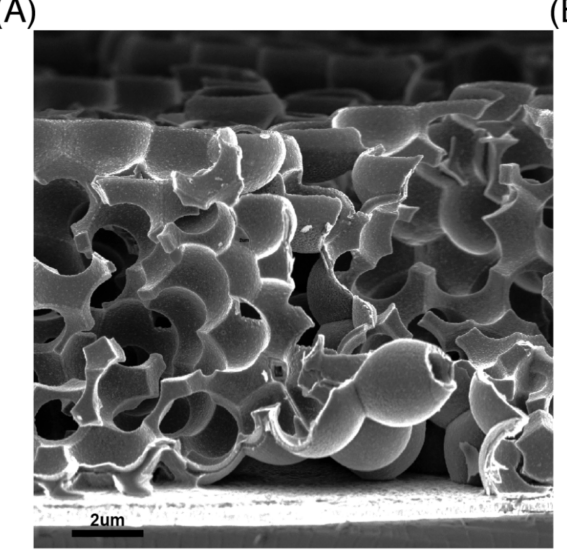

(B)
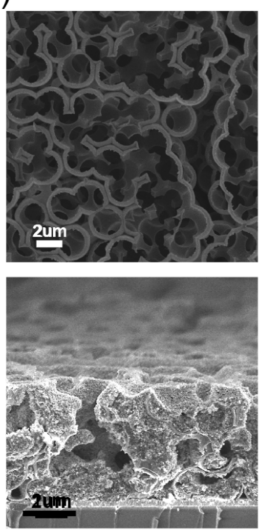

(E)
(C)

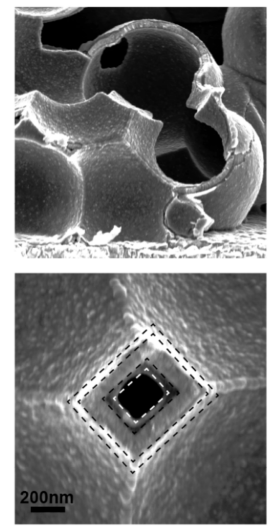

(D)

Figure 2. Scanning electron micrograph of a self-assembled $3 \mathrm{D} \mathrm{Al} / \mathrm{ZnO}\left|\mathrm{TiO}_{2}\right|$ host-guest dyes-sensitized solar cell photoanode. (A) Cross-sectional view of a disordered $\mathrm{TiO}_{2}$ passivated $3 \mathrm{D} \mathrm{Al} / \mathrm{ZnO}$ backbone. (B) Top-view of the $3 \mathrm{D}$ macroporous $\mathrm{Al} / \mathrm{ZnO}$ after top surface removal by reactive ion etching and template removal by annealing. (C) High-magnification micrograph showing the $\mathrm{TiO}_{2}$ covered $3 \mathrm{D}$ macroporous $\mathrm{Al} / \mathrm{ZnO}$ host in direct contact with the front FTO electrode. (D) High-magnification micrograph showing the $3 \mathrm{D} \mathrm{Al} / \mathrm{ZnO}$ conformally coated with a $25 \mathrm{~nm}$ thin film of dense $\mathrm{TiO}_{2}$ inside and out. (E) Complete photoanode after infiltration and calcination of the $\mathrm{TiO}_{2}$ nanoparticle paste.

The dispersion is then doctor bladed, a scalable fabrication technique, on a transparent conductive FTO-covered glass substrate to reveal a large-area highly light scattering disordered template (Figure 1a). It is then heated and infiltrated with $90 \mathrm{~nm}$ of $\mathrm{Al} / \mathrm{ZnO}(1: 9), \mathrm{SnO}_{2}$, or $\mathrm{TiO}_{2}$ in a highly conformal fashion by atomic layer deposition (ALD) by alternating pulses of organometallic precursors and hydrolytic polycondensation agent $\left(\mathrm{H}_{2} \mathrm{O}\right)$ in exposure mode (Figure $1 \mathrm{~b}$ ). Recently ALD has been gaining interest as a powerful research tool for creating highly conformal layers on nanostructured electrodes ${ }^{35}$ and has even been used for surface state passivation of $\mathrm{TiO}_{2}$ in dye sensitized solar cells and $\mathrm{Fe}_{2} \mathrm{O}_{3}$ in photolysis. ${ }^{36,37}$ The deposition temperature is optimized to increase the template interconnecting pore size by softening of the polymer beads ensuring proper sphere necking. ${ }^{38}$ Large interconnecting pores between spheres will enable proper filling with the guest nanocrystalline $\mathrm{TiO}_{2}$ later on. A quick dry reactive ion etching (RIE) of the infiltrated opal's top surface oxide is performed before removing the polymer template by annealing $\left(360{ }^{\circ} \mathrm{C}, 15 \mathrm{~min}\right.$.) We thus obtain a 3D host backbone that is well connected to the underlying FTO-glass front electrode. The direct electronic connection will ensure efficient charge extraction throughout the interconnected 3D H-P-G electrode. The surfaces of the TCO backbone are then conformally coated with $25 \mathrm{~nm}$ of dense $\mathrm{TiO}_{2}$ by ALD in order to reduce interfacial recombination between electrons in the highly conducting TCO backbone and the $\mathrm{I}_{3}^{-}$oxidized electrolyte (Figure 1c). ${ }^{27}$ After calcination $\left(500{ }^{\circ} \mathrm{C}, 15 \mathrm{~min}\right.$.) the hexagonal wurtzite, cassiterite, and anatase crystal structures of the $\mathrm{Al} / \mathrm{ZnO}$, $\mathrm{SnO}_{2}$, and $\mathrm{TiO}_{2}$, respectively, were confirmed by powder X-ray diffraction (see Supporting Information, Figure S1). In order to provide enough surface area for dye sensitization and efficient light harvesting, the macroporous inverse TCO backbone is infiltrated by sequential doctor-blading of a low viscosity $17 \mathrm{~nm}$ anatase nanocrystal paste (Figure 1d).

Scanning electron micrographs (SEM) of a $3 \mathrm{D} \mathrm{Al} / \mathrm{ZnO}$ $\left|\mathrm{TiO}_{2}\right|$ anatase nanoparticles $\mathrm{H}-\mathrm{P}-\mathrm{G}$ photoanode are presented in Figure 2. The cross-sectional and top view ( $\mathrm{Al} / \mathrm{ZnO}$ host) micrographs (Figure 2a,b) clearly show the high pore connectivity throughout the $3 \mathrm{D}$ open structure as well as the significant disorder inherited from the polystyrene template. From these micrographs, we can conclude that the backbone only uses a small volume fraction of the $3 \mathrm{D}$ film $(\sim 10 \%)$. This is an additional advantage of the $3 \mathrm{D}$ macroporous structure where the high degree of necking between the templating spheres and the very thin $(90 \mathrm{~nm})$ film of metal oxide host deposited leave the vast majority of the volume for filling with the guest material. The macroporous structure further enables the conformal coating of the $3 \mathrm{D}$ host on both sides with dense $\mathrm{TiO}_{2}$ by ALD (Figure $2 \mathrm{c}, \mathrm{d}$ ). The role of the $\mathrm{TiO}_{2}$ overlayer is to passivate the TCO surface to improve its chemical stability and further reduce recombination rate at the conductive transparent oxide - electrolyte interface. Visible in Figure 2c is the direct contact between the 3D host and the FTO-glass that will ensure unhindered electron transfer from the 3D host-guest structure and the front DSC electrode. Additionally, subsequent $\mathrm{TiO}_{2}$ deposition was found to cover the FTO in addition to the $3 \mathrm{D}$ host to effectively block recombination at the FTO-electrolyte interface. Figure 2e shows the 3D $\mathrm{Al} / \mathrm{ZnO}\left|\mathrm{TiO}_{2}\right|$ anatase nanoparticles $\mathrm{H}-\mathrm{P}-\mathrm{G}$ electrode after partial filling with mesoporous anatase to constitute the finished 3D TCO photoanode. We estimate from SEM pictures that about $50 \%$ on the internal volume is filled with the anatase $\mathrm{TiO}_{2}$ nanoparticles. The disordered structure and the partial filling at the scale of light combine to induce high optical scattering in the 3D H-P-G structure (see Supporting Information, Figure S2)

Complete DSC devices were prepared using $10-12 \mu \mathrm{m}$ thick $3 \mathrm{D} \mathrm{TiO}_{2}\left|\mathrm{TiO}_{2}\right|$ anatase nanoparticles, $\mathrm{Al} / \mathrm{ZnO}\left|\mathrm{TiO}_{2}\right|$ anatase nanoparticles and $\mathrm{SnO}_{2}\left|\mathrm{TiO}_{2}\right|$ anatase nanoparticles $\mathrm{H}-\mathrm{P}-\mathrm{G}$ photoanodes on a FTO-glass substrate. In both cases, $90 \mathrm{~nm}$ of the host and $25 \mathrm{~nm}$ of $\mathrm{TiO}_{2}$ were deposited by ALD for a maximum wall thickness of $140 \mathrm{~nm}$. Each of the macroporous 3D H-P-G structures were partially filled with a $17 \mathrm{~nm}$ anatase nanoparticle paste using a modified doctor blading procedure. Individual infiltrations were separated by $10 \mathrm{~min}$ heating at $120{ }^{\circ} \mathrm{C}$ to ensure solvent evaporation and densification of the conformal paste thin film. The electrode is then calcined to burn off the organic materials found in the paste $\left(500{ }^{\circ} \mathrm{C}, 60 \mathrm{~min}\right.$, $2{ }^{\circ} \mathrm{C} / \mathrm{min}$ ramp). ${ }^{39} \mathrm{In}$ order to improve the anatase nanoparticle 


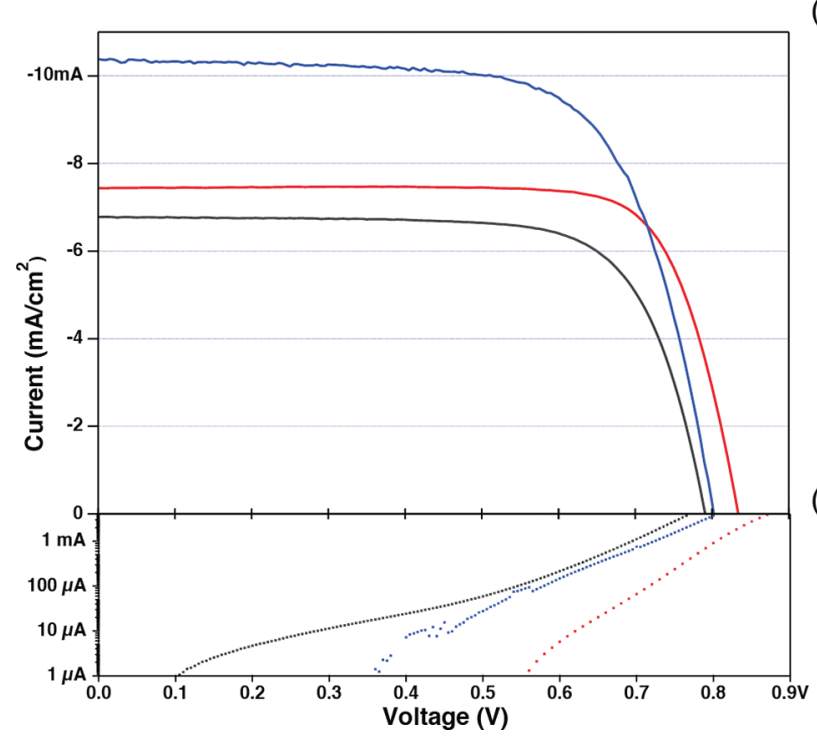

Figure 3. Photocurrent density-voltage $(J-V)$ characteristics of the 3D host-passivation-guest dye-sensitized solar cells under AM 1.5 illumination and in the dark. Solid (A) and dashed (B) lines represent the current under standard illumination and in the dark, respectively, for $\mathrm{Al} / \mathrm{ZnO}\left(\mathrm{red}, J_{\mathrm{sc}}=7.5 \mathrm{~mA} / \mathrm{cm}^{2}, V_{\mathrm{oc}}=842 \mathrm{mV}, \mathrm{ff}=0.77, \eta=4.9 \%\right.$ ), $\mathrm{SnO}_{2}$ (blue, $J_{\mathrm{sc}}=10.4 \mathrm{~mA} / \mathrm{cm}^{2}, V_{\mathrm{oc}}=803 \mathrm{mV}, \mathrm{ff}=0.70, \eta=5.8 \%$ ) and $\mathrm{TiO}_{2}$ (black, $J_{\mathrm{sc}}=6.9 \mathrm{~mA} / \mathrm{cm}^{2}, V_{\mathrm{oc}}=791 \mathrm{mV}, \mathrm{ff}=0.73, \eta=4.0 \%$ ) hosts.

connectivity and increase the photocurrent, the $\mathrm{TiO}_{2}$ and $\mathrm{SnO}_{2}$ $\mathrm{H}-\mathrm{P}-\mathrm{G}$ photoanodes were immersed into a $40 \mathrm{mM}$ aqueous $\mathrm{TiCl}_{4}$ solution at $70{ }^{\circ} \mathrm{C}$ for $30 \mathrm{~min}$ and washed with water and ethanol. ${ }^{39}$ This treatment could not be done on the $\mathrm{Al} / \mathrm{ZnO}$ based electrode since it is not chemically stable enough to sustain immersion in strong acid at elevated temperature. We should thus expect a penalty on the photocurrent for this photoanode.

The films are sintered for $30 \mathrm{~min}$ at $500^{\circ} \mathrm{C}$ before dipping in a $0.3 \mathrm{mM}$ Z907 solution for $10 \mathrm{~min}$. Z907 has been supplanted recently by ruthenium and organic dyes with higher molar coefficient but we were willing to sacrifice some photocurrent in exchange for high versatility and well-characterized photovoltaic characteristics enabling a direct comparison with published data (Z907: $J_{\mathrm{sc}}=17.13 \mathrm{~mA} / \mathrm{cm}^{2}, V_{\mathrm{oc}}=730 \mathrm{mV}$, ff $=0.724$, $\eta=9.05 \%) .{ }^{40}$ Following the immersion procedure, the dyesensitized electrodes were rinsed with acetonitrile and dried in air. The photoanodes are then assembled using a thermally platinized FTO (TEC15) counter electrode using a $25 \mu \mathrm{m}$ thick hot melt ring and sealed by heating. The cell internal space was filled with a $\mathrm{I}_{3}^{-} / \mathrm{I}^{-}$electrolyte in a 85:15 acetonitrile/valeronitrile mixture.

Shown in Figure 3a are the $J-V$ characteristics for the dyesensitized solar cells based on $\mathrm{TiO}_{2}, \mathrm{SnO}_{2}$, and $\mathrm{Al} / \mathrm{ZnO} 3 \mathrm{D}$ host photoanodes. We find an increase in short-circuit current density going from a $\mathrm{TiO}_{2}\left(J_{\mathrm{sc}}=6.9 \mathrm{~mA} / \mathrm{cm}^{2}\right)$ to $\mathrm{Al} / \mathrm{ZnO}\left(J_{\mathrm{sc}}=7.9 \mathrm{~mA} /\right.$ $\left.\mathrm{cm}^{2}\right)$ and $\mathrm{SnO}_{2}\left(J_{\mathrm{sc}}=10.4 \mathrm{~mA} / \mathrm{cm}^{2}\right)$. The photocurrent for the $\mathrm{Al} / \mathrm{ZnO}$ host is found to be significantly lower than that of $\mathrm{SnO}_{2}$ because of the lack of $\mathrm{TiCl}_{4}$ treatment on the former. This treatment enhances connectivity between anatase $\mathrm{TiO}_{2}$ nanoparticles to significantly increase the photocurrent and photovoltage in state-of-the-art DSCs by improving electron hopping at the anatase nanoparticle boundaries. ${ }^{41}$ Even though the $\mathrm{Al} /$ $\mathrm{ZnO}$ host is protected by $\mathrm{TiO}_{2}$ it is impossible to ensure a complete, pinhole free protection against the low $\mathrm{pH} \mathrm{TiCl}_{4}$ solution. It is possible that the increase in photocurrent observed is a direct consequence of the high electron mobility in the $\mathrm{Al} /$ $\mathrm{ZnO}$ and $\mathrm{SnO}_{2}$ hosts (241 and $16.5 \mathrm{~cm}^{2} /(\mathrm{V} \mathrm{s})$, respectively), which is 5-6 orders of magnitude higher than measured for anatase $\mathrm{TiO}_{2}$ nanoparticles at high voltage $(V=0.8 \mathrm{~V}, 2.30 \times$ $10^{-4} \mathrm{~cm}^{2} /(\mathrm{V} \mathrm{s})$ ) (see Supporting Information, Table S1). ${ }^{8}$ In addition, the fill factor is found to be greater for the $\mathrm{Al} / \mathrm{ZnO}$ ( $\mathrm{ff}=$ 0.77) host than for the $\mathrm{TiO}_{2}(\mathrm{ff}=0.73)$ host. Regardless of the host material, the 3D H-P-G photoanodes all present photovoltages well above the $V_{\mathrm{oc}}=730 \mathrm{mV}$ obtained with the best performing Z907 DSCs. ${ }^{40}$ Indeed, an improvement of 60 and $110 \mathrm{mV}$ for $\mathrm{TiO}_{2}\left(V_{\text {oc }}=791 \mathrm{mV}\right)$ and $\mathrm{Al} / \mathrm{ZnO}\left(V_{\text {oc }}=842 \mathrm{mV}\right)$ hosts are obtained, respectively. A significant increase in photovoltage is to be expected when reducing the dark current which depends on the conduction band position and recombination dynamics in the cell. Indeed, a significant decrease in the dark current is observed going from the $\mathrm{TiO}_{2}$ to the $\mathrm{Al} / \mathrm{ZnO}$ host as can be seen in $3 \mathrm{~b}$. Further variations in the $J-V$ characteristics for two additional dye/coadsorbent configurations (Z907/GBA and N719) are presented in the Supporting Information Figure S3.

When compared to previous studies using high mobility materials like $\mathrm{SnO}_{2}$ and $\mathrm{ZnO}$ passivated with $\mathrm{TiO}_{2}$ in liquid electrolyte DSCs we find that the photovoltage obtained with the 3D host-guest photoanodes are higher by at least 90-100 $\mathrm{mV} .^{7,23,28-30}$ Additionally, an increase of about 60 and $110 \mathrm{mV}$ over our published state-of-the-art values for Z907 dye and iodine-based volatile electrolyte is obtained for $3 \mathrm{D} \mathrm{TiO}_{2}$ and $\mathrm{Al} / \mathrm{ZnO}$ hosts, respectively. One of the major advantages in using transparent high mobility materials, for example, $\mathrm{ZnO}$ and $\mathrm{SnO}_{2}$, for charge injection and collection in DSCs lies in its relatively low transport resistance when compared to that of anatase $\mathrm{TiO}_{2}$ nanoparticles. ${ }^{42-44}$ However, this advantage was found to be counterbalanced by faster electron recombination dynamics with the oxidized electrolyte via intrabandgap surface states ultimately limiting the efficiency of such cells. ${ }^{44}$ This led to the study of various capping materials $\left(\mathrm{Al}_{2} \mathrm{O}_{3}, \mathrm{TiO}_{2}, \mathrm{MgO}\right.$, etc. $)$ that slow down recombination leading to increases in photocurrent and photovoltage. ${ }^{7,31,32}$ In addition to acting as an effective protection layer for the chemically unstable $\mathrm{ZnO}$ against the acidic dye solution, ${ }^{45}$ the complete coverage of the host material with ALD of a dense $25 \mathrm{~nm} \mathrm{TiO}_{2}$ layer can passivate surface traps ${ }^{37}$ and increase charge transfer resistance to the oxidized dye and electrolyte. This is clearly visible in the decrease in dark current observed (Figure 3b). According to the literature, this can be due to a decrease in recombination or a shift of the conduction band toward vacuum. Both would lead to a shift in the quasi-Fermi level with respect to the redox potential of the electrolyte and contribute to the significant increase in the observed photovoltage. ${ }^{7}$ These findings will motivate further mechanistic studies on the role of the various interfaces, conduction pathways, and electronic properties of the various materials that could induce band bending, affect injection dynamics, or shift the conduction band position.

In conclusion, we demonstrated a novel bottom-up 3D H-P-G DSC photoanode made of a high electron mobility host, a passivating conformal blocking layer and a high surface area guest to improve short circuit current density, fill factor, and photovoltage. The 3D H-P-G photoanode shows a strong decrease in dark current when using $\mathrm{Al} / \mathrm{ZnO}$ with electron mobility and diffusion coefficient up to 6 orders of magnitude higher than that of anatase $\mathrm{TiO}_{2}$ nanoparticles. By completely covering the $3 \mathrm{D}$ host with a dense passivating $\mathrm{TiO}_{2}$ thin film and 
filling its macropores with anatase nanoparticles, we ensure a high surface area for dye loading and maintain injection dynamics typical of anatase nanoparticle-based DSCs. Using this novel 3D H-P-G morphology partially filled with anatase nanoparticles, we show an increase in photovoltage of up to $110 \mathrm{mV}$ over state-ofthe-art $\mathrm{TiO}_{2}$ and $\mathrm{ZnO}$ DSCs with $\mathrm{Z} 907$ and $\mathrm{I}_{3}^{-} / \mathrm{I}^{-}$redox couple. The concept electrode is well suited for DSC since only a small volume fraction is lost to the transparent $3 \mathrm{D}$ host material leaving most of the volume for the light harvesting sensitized mesoporous anatase $\mathrm{TiO}_{2}$. The straightforward and simple bottom-up fabrication technique produces a highly optically scattering 3D photoanode material that could enhance light harvesting and charge extraction and reduce interfacial recombination to significantly increase the cell photovoltage, photocurrent and the fill factor in various low cost photovoltaic technologies. ${ }^{46}$

Methods. Three-Dimensional Host-Passivation-Guest Photoanode Fabrication. A $22 \mathrm{vol} \%$ dispersion of $2.2 \mu \mathrm{m}$ polystyrene macrospheres in isopropanol is doctor bladed on a TEC15 FTO-covered glass substrate to reveal a large-area highly light scattering disordered template. It is then heated and infiltrated with $90 \mathrm{~nm}$ of $\mathrm{Al} / \mathrm{ZnO}(1: 9), \mathrm{SnO}_{2}$, or $\mathrm{TiO}_{2}$ in a highly conformal fashion by atomic layer deposition (ALD) pulses of trimethylaluminum, diethylzinc and water $\left(\mathrm{Al}(\mathrm{Me})_{3}\right.$, $\left.\mathrm{Zn}(\mathrm{Et})_{2} \mid \mathrm{H}_{2} \mathrm{O}, 114{ }^{\circ} \mathrm{C}, 1: 9\right)$, tetrakis(dimethylamino)tin and ozone $\left(\mathrm{Sn}\left(\mathrm{NMe}_{2}\right)_{4} \mid \mathrm{O}_{3}, 200{ }^{\circ} \mathrm{C}\right)$ and tetrakis(dimethylamino)titanium and water $\left(\mathrm{Ti}\left(\mathrm{NMe}_{2}\right)_{4} \mid \mathrm{H}_{2} \mathrm{O}, 200^{\circ} \mathrm{C}\right)$ using nitrogen as a carrier gas (Cambridge Nanotech Savannah S100). The infiltrated opal's top surface oxide is removed by RIE (6 min, $1800 \mathrm{~W}, \mathrm{C}_{4} \mathrm{~F}_{8}$, Ar carrier gas, AMS200) performed before removing the polymer template by annealing $\left(360^{\circ} \mathrm{C}, 15 \mathrm{~min}\right.$.) The TCO backbone is then conformally coated with $25 \mathrm{~nm}$ of dense $\mathrm{TiO}_{2}$ by ALD in order to reduce interfacial recombination between electrons in the highly conducting TCO backbone and the $\mathrm{I}_{3}{ }^{-}$oxidized electrolyte (Figure 1c). ${ }^{27}$ The 3D H-P-G structures were filled with a $17 \mathrm{~nm}$ anatase nanoparticle paste through four sequential doctor blading separated by $10 \mathrm{~min}$ heating at $120{ }^{\circ} \mathrm{C}$ to ensure solvent evaporation and densification of the conformal paste thin film. The electrode is then calcined to burn off the organic materials found in the paste $\left(500{ }^{\circ} \mathrm{C}, 60 \mathrm{~min}, 2{ }^{\circ} \mathrm{C} / \mathrm{min} \mathrm{ramp}\right) .{ }^{39}$ In order to improve the anatase nanoparticle connectivity and increase the photocurrent, the $\mathrm{TiO}_{2}$ and $\mathrm{SnO}_{2} \mathrm{H}-\mathrm{P}-\mathrm{G}$ photoanodes were immersed into a $40 \mathrm{mM}$ aqueous $\mathrm{TiCl}_{4}$ solution at $70{ }^{\circ} \mathrm{C}$ for $30 \mathrm{~min}$ and washed with water and ethanol. ${ }^{39}$

Dye-Sensitized Solar Cell Fabrication. The 3D host-passivation-guest photoanodes are sintered for $30 \mathrm{~min}$ at $500{ }^{\circ} \mathrm{C}$ before dipping in a $0.3 \mathrm{mM}$ Z907 solution (90 vol\% 1:1 acetonitrile/tert-butanol, 10 vol\% DMF) for $10 \mathrm{~min}$. Following the immersion procedure, the dye-sensitized electrodes are rinsed with acetonitrile and dried in air. The photoanodes are then assembled using a thermally platinized FTO counter electrode (fabricated by spreading out a drop of $5 \mathrm{mM} \mathrm{H}_{2} \mathrm{PtCl}_{6}$ isopropanol solution on the FTO before treating it at $420{ }^{\circ} \mathrm{C}$ for $15 \mathrm{~min}$ ) using a $25 \mu \mathrm{m}$ thick hot melt ring (Surlyn, DuPont) and sealed by heating. The cell internal space was filled with a volatile $\mathrm{I}_{3}^{-} / \mathrm{I}^{-}$electrolyte (1.0 M DMII, 0.03 $\mathrm{M} \mathrm{I}_{2}, 0.5 \mathrm{M} \mathrm{TBP}, 0.05 \mathrm{M} \mathrm{LiI}$, $0.1 \mathrm{M}$ GuNCS), in a 85:15 acetonitrile/valeronitrile mixture through a predrilled hole using a vacuum pump.

Mobility Measurement on $\mathrm{Al} / \mathrm{ZnO}$ and $\mathrm{SnO}_{2}$. Electron mobility in $\mathrm{Al} / \mathrm{ZnO}$ and $\mathrm{SnO}_{2}$ was obtained using Hall Effect measurement (Microworld HMS-3000) on a $90 \mathrm{~nm}$ thick film on glass substrate at room temperature in the dark.
J-V Measurements. A $450 \mathrm{~W}$ xenon lamp (Oriel, U.S.A.) was used to provide an incident irradiance of $100 \mathrm{~mW} / \mathrm{cm}^{2}$ at the surface of the solar cells. The spectral output of the lamp was filtered using Schott K113 Tempax sunlight filter (Präzisions Glas \& Optik $\mathrm{GmbH}$, Germany) to reduce light mismatch between AM 1.5G and the simulated illumination to less than $2 \%{ }^{47} \mathrm{~J}-\mathrm{V}$ measurements were taken using a Keithley 2400 sourcemeter (Keithley, U.S.A.) by independently applying external voltage to the cell and measuring the photogenerated current. The size of the mask used to test the cells was $0.25 \mathrm{~cm}^{2}$.

Scanning Electron Microscopy. Film morphology was investigated using a high-resolution scanning electron microscope (LEO 1550, Zeiss) equipped with a GEMINI column and a Schottky Field Emission source. Images were acquired using an In-Lens Secondary Electron Detector.

\section{ASSOCIATED CONTENT}

S Supporting Information. Additional table and figures. This material is available free of charge via the Internet at http:// pubs.acs.org.

\section{AUTHOR INFORMATION}

\section{Corresponding Author}

*E-mail: (N.T.) nicolas.tetreault@epfl.ch; (G.A.O.) gozin@ chem.utoronto.ca.

\section{ACKNOWLEDGMENT}

N.T. wishes to thank Dr. Morgan Stefik for the XRD of $\mathrm{SnO}_{2}$. Research at EPFL was supported by the King Abdullah University of Science and Technology (KAUST, Award No KUSC1-015-21). J.B. received financial support from a Marie Curie Research Training Network, Hydrogen Project (MRTN-CT2006-032474). L.-P. H. received financial support from the Swiss National Science Foundation (Grant 200020_125163). This work was partially supported by the European project MULTIPLAT (NMP4-SL-2009-228943). For research at University of Toronto, G.A.O. is deeply indebted to the Government of Canada for a Research Chair in Materials Chemistry and Nanochemistry enabling this research at University of Toronto. In addition, he thanks the Natural Sciences and Engineering Research Council (NSERC) of Canada and the NSERC Solar Network for strong and sustained financial support of this work. E.A. thanks NSERC for a graduate scholarship.

\section{REFERENCES}

(1) Chiba, Y.; Islam, A.; Watanabe, Y.; Komiya, R.; Koide, N. Jpn. J. Appl. Phys. 2006, 45, L638-L640.

(2) Gao, F.; Wang, Y.; Shi, D.; Zhang, J.; Wang, M.; Jing, X. J. Am. Chem. Soc. 2008, 130, 10720-10728.

(3) Graetzel, M. Prog. Photovoltaics 2006, 14, 429-442.

(4) Dloczik, L.; Ileperuma, O.; Lauermann, I.; Peter, L.; Ponomarev, E.; Redmond, G.; Shaw, N.; Uhlendorf, I. J. Phys. Chem. B 1997, 101, 10281-10289.

(5) Kopidakis, N.; Schiff, E.; Park, N.; van de Lagemaat, J.; Frank, A. J. Phys. Chem. B 2000, 104, 3930-3936.

(6) van de Lagemaat, J.; Zhu, K.; Benkstein, K. D.; Frank, A. J. Inorg. Chim. Acta 2008, 361, 620-626.

(7) Martinson, A. B. F.; Elam, J. W.; Liu, J.; Pellin, M. J.; Marks, T. J.; Hupp, J. T. Nano Lett. 2008, 8, 2862-2866. 
(8) Abayev, I.; Zaban, A.; Fabregat-Santiago, F.; Bisquert, J. Phys. Status Solidi A 2003, 196, R4-R6.

(9) Wang, Q.; Ito, S.; Graetzel, M.; Fabregat-Santiagoa, F.; Mora-Sero, I.; Bisquert, J.; Bessho, T.; Imai, H. J. Phys. Chem. B 2006, 110, 25210-25221.

(10) Clifford, J. N.; Palomares, E.; Nazeeruddin, M. K.; Graetzel, M.; Durrant, J. R. J. Phys. Chem. C 2007, 111, 6561-6567.

(11) Zhang, Z.; Chen, P.; Murakami, T. N.; Zakeeruddin, S. M.; Graetzel, M. Adv. Funct. Mater. 2008, 18, 341-346.

(12) Snaith, H. J. Adv. Funct. Mater. 2010, 20, 13-19.

(13) O'Regan, B.; Schwartz, D. T.; Zakeeruddin, S. M.; Gratzel, M. Adv. Mater. 2000, 12, 1263-1267 .

(14) Bach, U.; Lupo, D.; Comte, P.; Moser, J.-E.; Weissörtel, F. Nature 1998, 395, 583-585.

(15) Snaith, H.J.; Moule, A. J.; Klein, C.; Meerholz, K.; Friend, R. H.; Graetzel, M. Nano Lett. 2007, 7, 3372-3376.

(16) Wang, M.; Liu, J.; Cevey-Ha, N.; Moon, S.-J.; Liska, P.; Humphry-Baker, R.; Moser, J.-E.; Gratzel, C.; Wang, P.; Zakeeruddin, S. M.; Graetzel, M. Nano Today 2010, 5, 169-174.

(17) Cai, N.; Moon, S.-J.; Cevey-Ha, L.; Moehl, T.; HumphryBaker, R.; Wang, P.; Zakeeruddin, S. M.; Graetzel, M. Nano Lett 2011, 11 (4), 1452-1456.

(18) Barnes, P. R. F.; Liu, L.; Li, X.; Anderson, A. Y.; Kisserwan, H.; Ghaddar, T. H.; Durrant, J. R.; O’Regan, B. C. Nano Lett. 2009, 9, 3532-3538.

(19) Kopidakis, N.; Benkstein, K.; van de Lagemaat, J.; Frank, A. J. Phys. Chem. B 2003, 107, 11307-11315.

(20) Nelson, J.; Haque, S.; Klug, D.; Durrant, J. Phys. Rev. B 2001, 63, 205321.

(21) Snaith, H.J.; Humphry-Baker, R.; Chen, P.; Cesar, I.; Zakeeruddin, S. M.; Graetzel, M. Nanotechnology 2008, 19, 424003.

(22) Law, M.; Greene, L.; Johnson, J.; Saykally, R.; Yang, P. Nat. Mater. 2005, 4, 455-459.

(23) Martinson, A. B. F.; Elam, J. W.; Hupp, J. T.; Pellin, M. J. Nano Lett. 2007, 7, 2183-2187.

(24) Mor, G.; Shankar, K.; Paulose, M.; Varghese, O.; Grimes, C. Nano Lett. 2006, 6, 215-218.

(25) Chen, P.; Brillet, J.; Bala, H.; Wang, P.; Zakeeruddin, S. M.; Graetzel, M. J. Mater. Chem. 2009, 19, 5325-5328.

(26) Tetreault, N.; Horváth, E.; Moehl, T.; Brillet, J.; Smajda, R.; Bungener, S.; Cai, N.; Wang, P.; Zakeeruddin, S. M.; Forró, L.; Magrez, A.; Graetzel, M. ACS Nano 2010, 4, 7644.

(27) Green, A.; Palomares, E.; Haque, S. A.; Kroon, J.; Durrant, J. J. Phys. Chem. B 2005, 109, 12525-12533.

(28) Kay, A.; Gratzel, M. Chem. Mater. 2002, 14, 2930-2935.

(29) Ramasamy, E.; Lee, J. J. Phys. Chem. C 2010, 114, 22032-22037.

(30) Yang, W.; Wan, F.; Chen, S.; Jiang, C. Nanoscale Res. Lett. 2009, 4, 1486-1492.

(31) Prasittichai, C.; Hupp, J. T. J. Phys. Chem. Lett. 2010, 1, 1611-1615.

(32) Snaith, H. J.; Ducati, C. Nano Lett. 2010, 10, 1259-1265.

(33) Miguez, H.; Tetreault, N.; Yang, S.; Kitaev, V.; Ozin, G. A. Adv. Mater. 2003, 15, 597-600.

(34) Tetreault, N.; Freymann, von, G.; Deubel, M.; Hermatschweiler, M.; Perez-Willard, F.; John, S.; Wegener, M.; Ozin, G. Adv. Mater. 2006, $18,457$.

(35) Kim, H.; Lee, H.-B.-R.; Maeng, W. J. Thin Solid Films 2009, $517,2563-2580$.

(36) Li, T. C.; Goes, M. S.; Fabregat-Santiagoa, F.; Bisquert, J.; Bueno, P. R.; Prasittichai, C.; Hupp, J. T.; Marks, T. J. J. Phys. Chem. C 2009, 113, 18385-18390.

(37) Le Formal, F.; Tetreault, N.; Cornuz, M.; Moehl, T.; Graetzel, M.; Sivula, K. Chem. Sci. 2011, 2, 737-743.

(38) Miguez, H.; Tetreault, N.; Hatton, B.; Yang, S.; Perovic, D.; Ozin, G. A. Chem. Commun. 2002, 2736-2737.

(39) Ito, S.; Murakami, T.; Comte, P.; Liska, P.; Gratzel, C. Thin Solid Films 2008, 516, 4613-4619.

(40) Cao, Y.; Bai, Y.; Yu, Q.; Cheng, Y.; Liu, S.; Shi, D.; Gao, F.; Wang, P. J. Phys. Chem. C 2009, 113, 6290-6297.

(41) O’Regan, B. C.; Durrant, J. R.; Sommeling, P. M.; Bakker, N. J. J. Phys. Chem. C 2007, 111, 14001-14010.
(42) Martinson, A. B. F.; McGarrah, J.; Parpia, M.; Hupp, J. Phys. Chem. Chem. Phys. 2006, 8, 4655-4659.

(43) Martinson, A. B. F.; Goes, M. S.; Fabregat-Santiago, F.; Bisquert, J.; Pellin, M. J.; Hupp, J. T. J. Phys. Chem. A 2009, 113, 4015-4021.

(44) He, C.; Zheng, Z.; Tang, H.; Zhao, L.; Lu, F. J. Phys. Chem. C 2009, 113, 10322-10325.

(45) Keis, K.; Magnusson, E.; Lindstrom, H.; Lindquist, S.; Hagfeldt, A. Sol. Energy Mater. Sol. Cells 2002, 73, 51-58.

(46) Moser, J.-E.; Wolf, M.; Lenzmann, F.; Graetzel, M. Z. Phys. Chem. 1999, 212, 85-92.

(47) Ito, S.; Matsui, H.; Okada, K.; Kusano, S.; Kitamura, T.; Wada, Y.; Yanagida, S. Sol. Energy Mater. Sol. Cells 2004, 82, 421-429. 